\title{
Home Photovoltaic System Design in Pangkalpinang City
}

\author{
Wahri Sunanda ${ }^{1, *}$ \\ ${ }^{1}$ Department of Electrical Engineering, Faculty of Engineering, Universitas Bangka Belitung, Bangka - Indonesia
}

\begin{abstract}
This research aims to obtain the design of home photovoltaic systems in Pangkalpinang and the opportunity of economic savings. The system consists of photovoltaic with batteries. Based on electricity consumption of several houses with installed power of 1300 VA and 2200 VA in Pangkalpinang for one year, the daily load of photovoltaic system is varied to $40 \%, 30 \%$ and $20 \%$ of the average value of the daily home electricity consumption. The investment costs, the cost of replacement parts and the cost of electricity consumption accrued to PLN during lifetime of systems (25 years) are also calculated. The result provided that there are no economic saving opportunities for photovoltaic systems with batteries at home with installed power of 1300 VA and 2200 VA in Pangkalpinang. The most economical is the photovoltaic system with the daily load of $20 \%$ of the average value of the daily home electricity consumption. The configuration of photovoltaic system for 1300 VA home consists of 10 modules of 200 wattpeak and 4 batteries $150 \mathrm{AH}, 12$ Volt while photovoltaic system for 2200 VA home consists of 15 modules of 200 wattpeak and 6 batteries $150 \mathrm{AH}, 12$ Volt.
\end{abstract}

\section{Introduction}

According to the statistical data of PT. PLN (Persero) Bangka Belitung region in 2016, currently there are some power plants connected with $607,226 \mathrm{kVA}$ and the amount of energy generated $839.68 \mathrm{GWh}$. The total electrical energy is supplied $60.1 \%$ by high speed diesel (HSD), 10, 6\% of biodiesel, $27.3 \%$ of coal and $1 \%$ of biomass, biogas and solar. The number of customers in 2016 was 388.752 with 357.093 household, 21.657 business, 6.065 social and 3.448 government. Therefore, the diversification of energy sources needs to be developed in the Bangka Belitung Islands Province.

Solar cell technology can be applied in Indonesia especially in Province Bangka Belitung because sunlight is accepted almost throughout the year. With solar cells, sunlight is converted into electric current. Then, the resulting energy can be stored in storage media (battery). The use of PLN's electrical energy combined with a photovoltaic system can help solve the problem of electricity especially when applied to households because this sector is the largest consumer of electrical energy.

Previously there has been a study related to the hybrid system of solar power plants with PLN electricity using batteries as storage of electrical energy (storage system) for urban homes, photovoltaic system supplies electrical energy about $30 \%$ of the overall load of household electrical appliances while the remaining $70 \%$ of electricity from PLN [1]. Then photovoltaic system planning with batteries as a medium for storing electrical energy has also been done to meet the electrical energy needs of 10 houses in housing complexes in Banda Aceh [2]. There has also been research related to the concept of regulating the flow of power for the photovoltaic system connected to the grid system at residential, grid as a storage or temporary lender to meet the demand of the load so that only the investment cost of the photovoltaic system without batteries and the cost of leasing the network needed in the home system with photovoltaic system [3].

Then a research to design a standalone solar photovoltaic system for residential application with total load power 1981 watt for some direct current (DC) appliances and alternative current (AC) appliances [4]. Then a system to supply electrical demand of a rural house without connection to national grid, using day to day necessary appliances, by photovoltaic system [5]. Also the design of a grid connected photovoltaic (PV) system for typical house will be discussed in terms of sizing of P-V units and battery storage [6]. There is also design of solar PV system and a case study based on cost analysis of $1.0 \mathrm{~kW}$ off-grid photovoltaic energy system and costs of energy produced installed at Jamia Millia Islamia, New Delhi India [7]. However, the prior related researches have not conducted an economic analysis of the designed photovoltaic system. The research is expected to provide a description of household electrical energy consumption patterns and become a consideration in the use of solar cell technology for households that are integrated with electricity from PLN (grid connected) in the framework of developing renewable energy utilization.

\section{Method}

Collect data of household electricity consumption in Pangkalpinang city with installed power of 1300 VA (30

\footnotetext{
Corresponding author: wahrisunanda@ubb.ac.id
} 
homes) and 2200 VA (30 homes) starting in April 2015 through March 2016. Then, perform data processing of household electrical energy consumption so it can be known the average value of daily electricity consumption. The daily load for the designed photovoltaic system in household is varied to three ie $40 \%, 30 \%$ and $20 \%$ of the average daily electricity consumption.

Make the design of photovoltaic systems with batteries connected to the household network/grid. The main components of photovoltaic systems with batteries are solar modules, BCR, batteries and inverters [12][13].

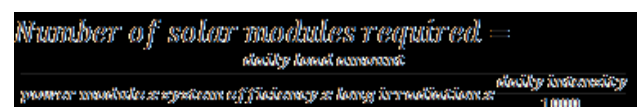

$$
\begin{aligned}
& \text { Capacity of battery }= \\
& \frac{\text { daily load amount } x \text { autonomous days }}{\text { battery efficiency } x \text { DOD } x \text { battery voltag }}
\end{aligned}
$$

Capacity of $B C R=$ Number of modules $x I_{s c}$

Capacity of inverter $=$ greater than the load power

$$
\text { load power }=\frac{\text { daily load amount }}{\text { load fulfillment time }}
$$

Finally, calculate total cost of photovoltaic system covering investment cost, component replacement cost during lifetime (25 years) and electricity consumption cost accrued to PLN during the system lifetime. Then, compare the total cost spent during the lifetime for the home with photovoltaic system and without photovoltaic system in order to know the feasibility and economic savings opportunities derived from the installation of the system photovoltaic in the house.

For calculation of component replacement cost during the lifetime of the photovoltaic system, it is assumed that the component price declines ( $8 \%$ per year) as a result of technological and industrial developments causing declining production costs [8]. Also assumed that the cost of household electricity consumption paid to PLN fixed during lifetime system because the electricity tariff not increase significantly each year.

\section{Results}

To determine the daily load of photovoltaic systems connected to the power grid, collected data of electric energy usage for 1 year from April 2015 to March 2016 in 30 households with installed power of $1300 \mathrm{VA}$ and 30 households with installed power of 2200 VA in Pangkalpinang city. The average daily household power consumption with $1300 \mathrm{VA}$ installed power is $9.51 \mathrm{kWh}$ while the average daily household consumption with 2200 VA installed is $14.68 \mathrm{kWh}$. The average value is then used to determine the daily load of photovoltaic systems connected to the household power grid.

In this paper, the design is photovoltaic system using battery. The total daily load of photovoltaic system is $40 \%, 30 \%$ and $20 \%$ of the average daily household electricity consumption. Daily consumption of 30 household electric power customers with installed power 1300 VA can be seen in figure 1 and with installed power 2200 VA in figure 2. The daily load of photovoltaic systems in households also can be seen in Table 1 .

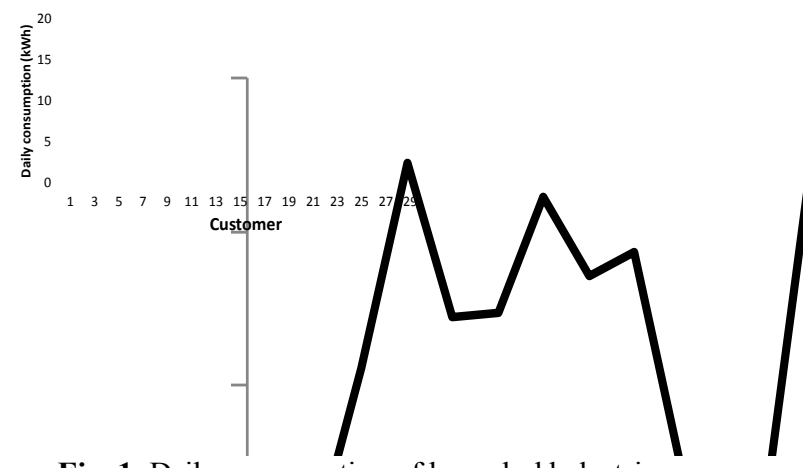

Fig. 1. Daily consumption of household electric power customers with installed power $1300 \mathrm{VA}(\mathrm{kWh})$

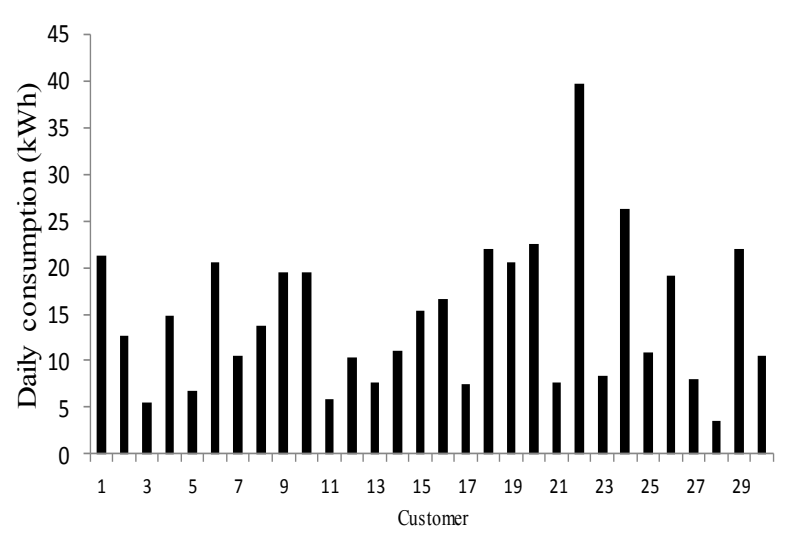

Fig. 2. Daily consumption of household electric power customers with installed power $2200 \mathrm{VA}(\mathrm{kWh})$

a. Photovoltaic system using storage media (battery) Photovoltaic systems use storage media (batteries) so that the electrical energy generated can be stored in advance to meet the electricity needs at night. The design is carried out at installed power of 1300 VA and 2200 VA by varying the amount of photovoltaic system loads to $40 \%$, $30 \%$ and $20 \%$ of the average daily consumption amount to know which photovoltaic system is most likely to be applied.

Table 2 shows the number of modules, inverter capacity, BCR capacity and battery capacity used for 1300 VA installed power with load variations of $40 \%, 30 \%$ and $20 \%$ with daily load of $3.8 \mathrm{kWh}, 2.85 \mathrm{kWh}$ and 1,902 $\mathrm{kWh}$ respectively. 
Table 1. Total daily load of photovoltaic systems

\begin{tabular}{cccc}
\hline $\begin{array}{c}\text { Installed } \\
\text { Power } \\
\text { Capacity }\end{array}$ & $\begin{array}{c}\text { Average } \\
\text { Daily } \\
\text { Electricity } \\
\text { Consumption }\end{array}$ & $\begin{array}{c}\text { Percentage of } \\
\text { Daily Load }\end{array}$ & Daily Load \\
\hline \multirow{2}{*}{$1300 \mathrm{VA}$} & $9,51 \mathrm{kWh}$ & $30 \%$ & $2,850 \mathrm{kWh}$ \\
& & $20 \%$ & $1,902 \mathrm{kWh}$ \\
& & $40 \%$ & $5,870 \mathrm{kWh}$ \\
$2200 \mathrm{VA}$ & $14,68 \mathrm{kWh}$ & $30 \%$ & $4,400 \mathrm{kWh}$ \\
& & $20 \%$ & $2,936 \mathrm{kWh}$ \\
\hline
\end{tabular}

Table 2. Photovoltaic systems using batteries connected with the power grid for homes with $1300 \mathrm{VA}$ installed power

\begin{tabular}{|c|c|c|c|c|}
\hline $\begin{array}{l}\text { System } \\
\text { daily } \\
\text { load }\end{array}$ & $\begin{array}{c}\text { Number } \\
\text { of } \\
\text { modules }\end{array}$ & $\begin{array}{c}\text { Capacity } \\
\text { of } \\
\text { inverter }\end{array}$ & $\begin{array}{l}\text { Capacity } \\
\text { of BCR }\end{array}$ & $\begin{array}{l}\text { Battery } \\
\text { capacity }\end{array}$ \\
\hline $\begin{array}{c}3,8 \\
\mathrm{kWh}\end{array}$ & 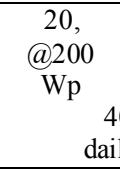 & $\begin{array}{l}300 \mathrm{~W}, \\
24 \mathrm{~V} \\
(2 \text { units) } \\
\text { of the ave } \\
\text { lectricity c }\end{array}$ & $\begin{array}{l}\text { 80A, 24V } \\
\text { (2 units) } \\
\text { e value } \\
\text { sumption }\end{array}$ & $\begin{array}{c}150 \mathrm{Ah}, 12 \mathrm{~V} \\
(8 \text { units })\end{array}$ \\
\hline $\begin{array}{l}2,85 \\
\mathrm{kWh}\end{array}$ & $\begin{array}{c}15, \\
@ 200 \\
\mathrm{Wp} \\
3 \\
\text { dai }\end{array}$ & $\begin{array}{c}300 \mathrm{~W}, \\
24 \mathrm{~V} \\
(1 \text { unit) } \\
\text { of the ave } \\
\text { lectricity c }\end{array}$ & $\begin{array}{c}100 \mathrm{~A}, \\
24 \mathrm{~V} \\
\text { (1 unit) } \\
\text { e value } \\
\text { sumption }\end{array}$ & $\begin{array}{c}150 \mathrm{Ah}, 12 \mathrm{~V} \\
(6 \text { units })\end{array}$ \\
\hline $\begin{array}{l}1,902 \\
\mathrm{kWh}\end{array}$ & $\begin{array}{l}10, \\
@ 200 \\
\text { Wp }\end{array}$ & $\begin{array}{c}300 \mathrm{~W}, \\
24 \mathrm{~V} \\
(1 \text { unit) }\end{array}$ & $\begin{array}{l}\text { 80A, } 24 \mathrm{~V} \\
\text { (1 unit) }\end{array}$ & $\begin{array}{c}150 \mathrm{Ah}, 12 \mathrm{~V} \\
(4 \text { units })\end{array}$ \\
\hline & & $\begin{array}{l}\text { of the ave } \\
\text { lectricity }\end{array}$ & $\begin{array}{l}\text { e value } \\
\text { sumption }\end{array}$ & \\
\hline
\end{tabular}

Table 3 shows that for home of $2200 \mathrm{VA}$ with load $40 \%$, $30 \%$ and $20 \%$ which is $5.87 \mathrm{kWh}, 4.4 \mathrm{kWh}$ and 2,936 $\mathrm{kWh}$ respectively, the number of modules, inverters, BCR and batteries used are different compared to $1300 \mathrm{VA}$ installed power

b. Economic analysis of designed photovoltaics systems The economic analysis of the designed photovoltaic system is done by determining the assumption that the PLN electricity tariffs remain for the lifetime while the price of photovoltaic components decreases $(8 \%$ per year). The calculation of the investment cost of the designed photovoltaic system, the cost of replacing the system components during the lifetime ( 25 years) and the accrued electricity cost to PLN during the lifetime of the system ( 25 years) is performed to determine the total cost required to meet household electricity needs during 25 years

The amount of electrical energy that must remain supplied by PLN, if reduced by the electric energy supplied by photovoltaic to meet the average daily electrical energy is shown in table 4.
Table 3. Photovoltaic systems using batteries connected with the power grid for homes with $2200 \mathrm{VA}$ installed power

\begin{tabular}{|c|c|c|c|c|}
\hline $\begin{array}{c}\text { System } \\
\text { daily load }\end{array}$ & $\begin{array}{c}\text { Number } \\
\text { of } \\
\text { modules }\end{array}$ & $\begin{array}{c}\text { Capacity } \\
\text { of } \\
\text { inverter }\end{array}$ & $\begin{array}{l}\text { Capacity } \\
\text { of BCR }\end{array}$ & $\begin{array}{l}\text { Battery } \\
\text { capacity }\end{array}$ \\
\hline \multirow[t]{2}{*}{$5,87 \mathrm{kWh}$} & $\begin{array}{c}30 \\
@ 200 \\
W p\end{array}$ & $\begin{array}{c}300 \mathrm{~W}, \\
24 \mathrm{~V} \\
(2 \text { units })\end{array}$ & $\begin{array}{c}100 \mathrm{~A}, \\
24 \mathrm{~V} \\
\text { (2 units) }\end{array}$ & $\begin{array}{c}150 \mathrm{Ah}, \\
12 \mathrm{~V} \\
(12 \\
\text { units) }\end{array}$ \\
\hline & \multicolumn{3}{|c|}{$\begin{array}{l}40 \% \text { of the average value } \\
\text { daily electricity consumption }\end{array}$} & \\
\hline \multirow[t]{2}{*}{$4,4 \mathrm{kWh}$} & $\begin{array}{c}22, \\
@ 200 \\
\text { Wp }\end{array}$ & $\begin{array}{c}300 \mathrm{~W} \\
24 \mathrm{~V} \\
(2 \text { units })\end{array}$ & $\begin{array}{l}80 \mathrm{~A}, 24 \mathrm{~V} \\
\text { (2 units) }\end{array}$ & $\begin{array}{c}200 \mathrm{Ah} \\
\text { (4 units) } \\
, 150 \mathrm{Ah} \\
\text { (4 units) }\end{array}$ \\
\hline & \multicolumn{3}{|c|}{$\begin{array}{l}30 \% \text { of the average value } \\
\text { daily electricity consumption }\end{array}$} & \\
\hline \multirow[t]{2}{*}{$2,936 \mathrm{kWh}$} & $\begin{array}{c}15, \\
@ 200 \\
\text { Wp }\end{array}$ & $\begin{array}{c}300 \mathrm{~W} \\
24 \mathrm{~V} \\
\text { (1 unit) }\end{array}$ & $\begin{array}{c}100 \mathrm{~A} \\
24 \mathrm{~V} \\
\text { (1 unit) }\end{array}$ & $\begin{array}{c}\text { 150Ah, } \\
12 \mathrm{~V} \\
\text { (6 units) }\end{array}$ \\
\hline & \multicolumn{3}{|c|}{$\begin{array}{l}20 \% \text { of the average value } \\
\text { daily electricity consumption }\end{array}$} & \\
\hline
\end{tabular}

Table 4. Total daily household electricity needs still to be met by PLN

\begin{tabular}{cc}
\hline Installed power (VA) & Energy (kWh) \\
\hline 1300 & 5,71 \\
& 6,66 \\
2200 & 7,608 \\
& 8,81 \\
& 10,28 \\
& 11,744 \\
\hline
\end{tabular}

Table 5. The cost of a photovoltaic system using batteries connected with power grid on a house with installed power of $1300 \mathrm{VA}$

\begin{tabular}{|c|c|c|c|}
\hline \multirow[t]{2}{*}{$\begin{array}{c}\text { Cost } \\
\text { Component }\end{array}$} & \multicolumn{3}{|c|}{$\begin{array}{c}\text { Total daily load of photovoltaic systems } \\
(\mathrm{kWh})\end{array}$} \\
\hline & 3,8 & 2,85 & 1,902 \\
\hline $\begin{array}{l}\text { Investment } \\
\text { costs }(\mathrm{Rp})\end{array}$ & 124.716 .000 & 91.578 .000 & 62.358 .000 \\
\hline $\begin{array}{l}\text { Cost of } \\
\text { component } \\
\text { replacement } \\
\text { (Rp) }\end{array}$ & 33.027 .720 & 22.808 .230 & 16.513 .860 \\
\hline $\begin{array}{c}\text { PLN's } \\
\text { electricity } \\
\text { consumption } \\
\text { costs for } 25 \\
\text { years (Rp } \\
1410,12 / \mathrm{kWh})\end{array}$ & 72.466 .067 & 84.522 .593 & 96.553 .737 \\
\hline $\begin{array}{l}\text { Total cost } \\
(\mathrm{Rp})\end{array}$ & 230.209 .787 & 198.908 .823 & 175.425 .597 \\
\hline
\end{tabular}


Table 6. Savings opportunity of the installation of photovoltaic systems using batteries connected to the network/grid at home with $1300 \mathrm{VA}$ installed power

\begin{tabular}{|c|c|c|c|}
\hline & \multicolumn{3}{|c|}{ Cost of electricity consumption (Rp) } \\
\hline $\begin{array}{l}\text { Home without } \\
\text { photovoltaic } \\
\text { system for } 25 \\
\text { years }\end{array}$ & & 120.692 .17 & \\
\hline \multirow{2}{*}{$\begin{array}{c}\text { Home with } \\
\text { photovoltaic } \\
\text { system for } 25 \\
\text { years }\end{array}$} & $\begin{array}{c}40 \% \\
\text { PV } \\
\text { Load }\end{array}$ & $30 \%$ PV Load & $20 \%$ PV Load \\
\hline & $\begin{array}{c}230.20 \\
9.787\end{array}$ & 198.908 .823 & 175.425 .597 \\
\hline $\begin{array}{l}\text { Difference cost } \\
\text { for } 25 \text { years }\end{array}$ & $\begin{array}{c}- \\
109.51 \\
7.616\end{array}$ & -78.216 .652 & -54.733 .426 \\
\hline
\end{tabular}

Table 5 shows that the cost of electricity consumption of house with photovoltaic systems connected to power lines using batteries for 25 years is still much larger when compared to the cost of electricity consumption if all the electricity needs of the house is met by PLN. Then table 6 shows the total cost for the smallest system lifetime is Rp 175.425.597 when the photovoltaic system meets $20 \%$ of the household's daily power supply $(1,902 \mathrm{kWh})$. For this photovoltaic system, the cost of electricity consumption per month is more expensive Rp 182.445 than if the house does not use photovoltaic.

Table 7. The cost of a photovoltaic system using batteries connected with power grid on a house with installed power of $2200 \mathrm{VA}$

\begin{tabular}{|c|c|c|c|}
\hline \multirow[t]{2}{*}{$\begin{array}{c}\text { Cost } \\
\text { Component }\end{array}$} & \multicolumn{3}{|c|}{$\begin{array}{l}\text { Total daily load of photovoltaic systems } \\
\text { (kWh) }\end{array}$} \\
\hline & 5,87 & 4,4 & 2,936 \\
\hline $\begin{array}{l}\text { Investment } \\
\text { costs (Rp) }\end{array}$ & 183.156 .000 & 136.956 .000 & 91.578 .000 \\
\hline $\begin{array}{l}\text { Cost of } \\
\text { component } \\
\text { replacement } \\
(\mathrm{Rp})\end{array}$ & 45.616 .460 & 35.823 .525 & 22.808 .230 \\
\hline $\begin{array}{c}\text { PLN's } \\
\text { electricity } \\
\text { consumption } \\
\text { costs for } 25 \\
\text { years (Rp } \\
1410,12 / \mathrm{kWh})\end{array}$ & 111.808 .415 & 130.464 .302 & 149.044 .044 \\
\hline $\begin{array}{l}\text { Total cost } \\
\text { (Rp) }\end{array}$ & 340.580 .875 & 303.243 .827 & 263.430 .274 \\
\hline
\end{tabular}

Table 7 shows that the cost of electricity consumption of homes with photovoltaic systems connected to power lines by using batteries for 25 years is still much larger when compared to the cost of electricity consumption if all the electricity needs of the house is met by PLN. Then table 8 shows the lowest total cost during the system lifetime is $\mathrm{Rp} 263.430 .274$ when the photovoltaic system meets $20 \%$ of the household's daily electrical load $(2,936$ $\mathrm{kWh}$ ). For this photovoltaic system, the cost of electricity consumption per month is more expensive Rp 257.084 than if the house does not use photovoltaic.

Table 8. Savings opportunity of the installation of photovoltaic systems using batteries connected to the network/grid at home with 2200 VA installed power

\begin{tabular}{|c|c|c|c|}
\hline & \multicolumn{3}{|c|}{ Cost of electricity consumption (Rp) } \\
\hline $\begin{array}{c}\text { Home } \\
\text { without } \\
\text { photovoltaic } \\
\text { system } \\
\text { for 25 years }\end{array}$ & \multicolumn{3}{|c|}{186.305 .054} \\
\hline \\
\hline $\begin{array}{c}\text { Home with } \\
\text { photovoltaic } \\
\text { system for 25 } \\
\text { years }\end{array}$ & $40 \%$ PV Load & $30 \%$ PV Load & $20 \%$ PV Load \\
\cline { 2 - 4 } & 340.580 .875 & 303.243 .827 & 263.430 .274 \\
\hline $\begin{array}{c}\text { Difference } \\
\text { cost for 25 } \\
\text { years }\end{array}$ & -154.275 .821 & -116.938 .773 & -77.125 .220 \\
\cline { 2 - 4 } & & & \\
\hline
\end{tabular}

\section{Conclusions}

From the research that has been done, it is known that there is no economic savings for photovoltaic systems connected to PLN power grids with battery-mounted system at home with $1300 \mathrm{VA}$ and $2200 \mathrm{VA}$ installed power in Pangkalpinang city. From some variations of photovoltaic systems that have been designed, the most economical is the photovoltaic system using batteries connected to the power grid with daily load of $20 \%$ of average daily household electricity consumption.

Photovoltaic system yet shows the feasibility in the economy, but the photovoltaic system is still feasible to be considered and implemented on a frequent home experienced a power outage, especially during the day.

\section{Acknowledgement}

This research was supported by Universitas Bangka Belitung year 2017.

\section{References}

1. L. E. B. L. E. Bien, I. Kasim, W. Wibowo, Jurnal Teknik Elektro, Vol. 8, No 1, Universitas Trisakti, Jakarta (2008).

2. Suriadi, M. Syukri., Jurnal Rekayasa Elektrika, Vol. 9, No. 2, Universitas Syiah Kuala, Banda Aceh (2010).

3. K. Kananda, R. Nazir., Jurnal Nasional Teknik Elektro,Vol. 2, No. 2, Universitas Andalas, Padang (2013). 
4. U.H.Ibrahim, D.A. Aremu, J.I. Unwaha., International Journal Of Scientific \& Technology Research Vol. 2, Issue 12, December (2013).

5. M. Aminy, N. Barhemmati,A. Hadadian, F.Vali., Design Of A Photovoltaic System For A Rural House, Second Iranian Conference on Renewable Energy and Distributed Generation (2012).

6. A.T. Elsayed, T.A. Youssef, A. Mohamed, O. A. Mohammed, Design, Control and Management of P-V System for Residential Applications with Weak Grid Connection, Eleventh LACCEI Latin American and Caribbean Conference for Engineering and Technology, Mexico (2013).

7. S. Ahsan, K. Javed, A. S. Rana, M. Zeeshan, Design And Cost Analysis Of $1 \mathrm{~kW}$ Photovoltaic System Based On Actual Performance In Indian Scenario, Perspectives in Science Vol. 8, pp 642-644 (2016).

8. G. Parkinson., Cost Reduction (Example:USA), http://reneweconomy.com.au, accessible date on September $6^{\text {th }}(2015)$.
9. Anonim, Penetapan Penyesuaian Tarif Tenaga Listrik Bulan Agustus 2016, http://www.pln.co.id, accessible date on August $18^{\text {th }}$ (2016).

10. G. Boyle., Renewable Energy, Power for a Sustainable Future, Oxford University Press, Inc., New York (1996).

11. R. Boylestad, L. Nashelsky., Electronic Devices and Circuit Theory, Prentice Hall International, Inc., New York (2002).

12. M. Buresch., Photovoltaic Energy Systems, Design and Installation, McGraw-Hill, Inc., New York (1983).

13. H. Djojodihardjo., Pengantar Ringkas Sistem Listrik Tenaga Surya, Institut Teknologi Bandung, Bandung (2001).

14. R.J. Kodoatie., Analisis Ekonomi Teknik, Andi, Yogyakarta (2002).

15. Available online on : https://solar.schneiderelectric.com/solutions/residential/ 